OPEN ACCESS

Edited by:

Dorota Lasota

Medical University of Warsaw, Poland

Reviewed by:

Muhammad Zaly Shah,

University of Technology

Malaysia, Malaysia

Witold Pawłowski,

Medical University of Lublin, Poland

*Correspondence:

Francisco Alonso

francisco.alonso@uv.es

Specialty section:

This article was submitted to

Governance and Cities,

a section of the journal

Frontiers in Sustainable Cities

Received: 15 May 2020

Accepted: 27 July 2020

Published: 02 September 2020

Citation:

Alonso F, Useche SA, Faus M and Esteban C (2020) Does Urban Security Modulate Transportation Choices and Travel Behavior of Citizens? A National Study in the Dominican Republic.

Front. Sustain. Cities 2:42. doi: 10.3389/frsc.2020.00042

\section{Does Urban Security Modulate Transportation Choices and Travel Behavior of Citizens? A National Study in the Dominican Republic}

\author{
Francisco Alonso*, Sergio A. Useche, Mireia Faus and Cristina Esteban \\ DATS (Development and Advising in Traffic Safety) Research Group, INTRAS (Research Institute on Traffic and Road Safety), \\ University of Valencia, Valencia, Spain
}

Introduction: Traditionally, the scientific literature on urban and transportation dynamics addresses many topics, but the security-related outcomes of users remain a pending issue, especially in emerging countries and their cities. Nevertheless, recent evidence suggests that, especially in developing countries, security issues may influence people's decision-making in the choice of transport means, daily urban-trip patterns and road behaviors of users.

Objective: The purpose of this study was to explore the relationships between the perceived security (in both urban environments and public transport systems) and the daily-travel behavior and trip patterns of the Dominican Republic population.

Methods: This cross-sectional study, performed in 2019, analyzed data collected from 1,026 inhabitants from different cities of the Dominican Republic (54\% females and $46 \%$ males), who completed a survey on security issues, travel behaviors and transportation-related habits.

Results: The results of this research suggest that demographic factors, such as age, education, and city/town size, and the safety perceived in the urban environment play a significant role in the choice of transportation modes, as well as in the participants' experience as victims of crime-related incidents (either witnessing or suffering crime episodes on public transport or city streets) during urban trips performed over the last 5 years.

Conclusion: Overall, the results of this study suggest that perceived safety, in both urban environments and public transport systems, is a relevant issue affecting the daily transport-related patterns and behavioral choices of the Dominican Republic's population. The results of this research might contribute to the strengthening of transport security planning, considering factors that are not traditionally kept in mind for policymaking in transportation dynamics.

Keywords: Dominican Republic, travel behavior, perceived security, urban security, transportation security 


\section{INTRODUCTION}

As it is already well-known that many factors could be -either directly or indirectly- related to people's decision making on transportation means, the literature seems to be properly scoped on many crucial facets such as health, safety, and servicerelated settings (Herman et al., 1959; Syed et al., 2013; MuroRodríguez et al., 2017): however, further key issues -such as the user's perceived security- are still considerably understudied in many regions, especially among those presenting several shortcomings and emerging needs in this matter. This is the case of the so-called emerging countries and their cities, in which aspects such as social gaps, developmental trends, and new social challenges might be affecting the way in which the daily movements of the population take place (Zhang et al., 2005). Hence, many studies endorse the hypothesis that exploring specific factors affecting travel behaviors of the population might allow for the strengthening of a safer and more inclusive mobility, through the establishment of adequate strategies and measures to promote safer and more sustainable transport modes (Schneider, 2013).

From a psychosocial perspective, transport dynamics have been traditionally associated with factors related to cost-benefit balances and planned behaviors (Cantarella and Cascetta, 1995). However, balance models are only useful under the assumption of representativeness, existence, uniqueness and stability. Therefore, more dynamic models of transportationrelated issues may be also addressed following both the deterministic and stochastic approaches (Sánchez-Flores and De Palma, 2013). This way, throughout the years, other explicative factors playing a role in the choice of a transport modes have been studied. Thus, environmental concerns, international growth, the development of the internet and new technologies are three of the most studied elements in this field (Waller et al., 2008). Moreover, some other research has developed theories to explain the choices of habitual transport modes, mainly taking into account elements related to awareness and availability, cost and convenience, enjoyment of the use, habits, and basic safety (Schneider, 2013).

In this sense, the relation between the security level of the urban environment and the choice of (e.g.) commuting routes, trip schedules and transport modes has already been empirically endorsed through various studies performed in other countries (Alm and Lindberg, 2002; Lai and Chen, 2011). People tend to choose transport modes that they perceive as safer (Beirão and Cabral, 2007). Therefore, it is interesting to research the relation between transport mode and road safety elements, such as the traffic accidents in which the road user has been involved. In this sense pedestrians, cyclists, and motorcycle users are the most vulnerable users, since they are much less protected on the road (Kim et al., 2007). It is interesting that, despite this situation of vulnerability, cyclists perceive a lower risk of crashing with cars, if compared with what drivers perceive in the same situation (Chaurand and Delhomme, 2013). The existing positive relation between perceived safety and risky driving is also clear, and it is based on the excessive confidence of experimented drivers, which has an impact on traffic accidents (Ho et al., 2015; Ho and Widaningrum, 2016); however, many similar relationships are still unexplored among non-motorized users, such as pedestrians and public transportation passengers.

The present research proposes, in addition, that the security (both objective and perceived) of citizens can play an important role in the choice of transport modes and in the traffic accidents suffered by users. Urban safety is a complex phenomenon that is developed from different perspectives (Arriagada and Godoy, 2000). In general terms, it is understood as the concern for both quality of life and human dignity (ILPES, 1997). From another perspective (which we adopt in this research), citizens' perception of security is characterized by the enjoyment of one's daily potential activities, without fears of (e.g.) being assaulted, suffering an aggression, as well as to walk along the streets without being afraid of robbery attempts (PNUD, 1998). This concept is tightly related to public order, personal safety/security and the overall safety of the population (Vidales, 2012). We must highlight not only that citizens' safety and security is objectively important, but also that researchers need to consider subjective perceptions to holistically understand how they affect the individual's well-being at different levels (Vidales, 2012).

This way, this research attempts to establish a relation between the choice of transport modes of citizens, road safety, and the perceived urban security in the Dominican Republic. This is a country located in Central America, with more than 10.5 million of inhabitants, and it counts on various types of public and private transport systems.

Data from the National Survey on Mobility from 2019 expose that, although more than $60 \%$ of the population has a private vehicle, motorcycles (that are cheaper and more accessible for the general population) constitute the majority of them, and cars are less frequently found. Furthermore, the use of public transport for daily movements is quite frequent: only as a figure, it is estimated that more than a half of commuting trips are performed on public transport, which is frequently used by more than $58 \%$ of the population (INTRANT, 2020). In this regard, the most used transport modes are public buses ("guagua"), and either formal or informal moto-taxis ("motoconchos"). On the other hand, the most valued public vehicle is the subway, even though it is less used, especially because (among other reasons) it is only available in the most urbanized zones of the country (INTRANT, 2020).

Additionally, if factors such as the low average income and social inequality are considered, the improvement of the current public transportation modes, that are expected to continue to experience a massive and increasing use during the following years, results crucial for daily life dynamics of Dominicans (Carneiro and Sirtaine, 2017; INTRANT, 2020). Nevertheless, and although public transportation has proven to be essential in the Dominican Republic, many residents face daily securityrelated challenges that can potentially affect their welfare: according the National Mobility Survey from 2019, safety is the most relevant concern of private vehicle users, while the perception of danger in the streets and transportation means is predominant among people who do not own a vehicle (INTRANT, 2020); this substantial gap provides clues of this factor influencing the choice of transport modes, an aspect that we aim at researching in this study. 


\section{Objective of the Study}

The main objective of this research was to study the relationships between the perceived security (in both urban environments and public transport systems) and the daily-travel behavior and trip patterns among the Dominican Republic population. Moreover, we studied differences in three sociodemographic variables: age, level of education, and city/town size, as well as the percentage of individuals who have witnessed/suffered security threats while performing urban trips.

\section{METHODS AND MATERIALS}

\section{Participants}

This cross-sectional study analyzed the data gathered from 1,026 inhabitants from different cities of the Dominican Republic, who completed a questionnaire on safety and other issues related to transportation in the year 2019. Approximately $54 \%$ of them were females and $46 \%$ males. The mean age was $M=31.88$ (SD = 13.45) years. Further demographic features of the study sample are shown in Table $\mathbf{1}$.

\section{Design, Procedure and Instruments}

This study used an observational cross-sectional method. The sample design was performed by means of a simple random sampling proportional to age, sex, and region of the Dominican population. The minimum sample size was initially established at about $n=660$ subjects, if a margin error for the general data of $5 \%$ is considered, with a confidence interval of $95 \%$ in the least favorable case of $p=q=50 \%$. However, this study achieved an even wider sample size, composed of 1,026 participants. Some comparisons of key demographic features between the study sample and the populational data are shown in Table 2.

The data were gathered through a street-conducted questionnaire, that retrieved a convenience sample based on the accessibility to the population. The average duration of the survey was $15 \mathrm{~min}$, and it was carried out anonymously, to protect the participants' identity. It is worth highlighting that the data were used for statistical research purposes only, and participation was voluntary and anonymous. The inclusion/exclusion criteria were: (1) being over 18 years old, and (2) regularly (at least once a week) performing urban trips in one's cities, regardless of their duration and geographical coverage. To answer the survey, participants were informed about the basic principles of privacy, personal data treatment and confidentiality. Participants' consent was required by researchers. The total of discarded (incomplete or unclear forms) surveys was 41 .

In order to achieve the purpose of our study, participants were asked about the following variables.

\section{Sociodemographic Features}

Participants were asked about their: sex/gender, age, educational level, current occupation, size of the city/town of residence.

\section{Daily Travel Patterns}

Once the participants were socio-demographically characterized, they were asked about the most frequent transportation means used for their daily movements; the average duration (measured in minutes) of their commuting trips (i.e., trips performed to/from work or studies center, in case of students); the frequency of public transport use; and the main reason for performing their usual urban trips.

\section{Perceived Security Assessment}

Additionally, they were asked to rate, in a 1-5 scale (being $1=$ totally unsafe and $5=$ totally safe) the security they perceived in their (a) urban environment (city/town of residence), and (b) the public transportation system available in their city or town.

\section{Experiences of Direct Victimization or Crime-Witnessing}

Finally, participants were inquired about their past experiences (in a time frame of 5 years before the survey), asking if: (a) they had witnessed (although not suffered) an unsafe incident (i.e., theft attempts) in the city's street or public transport system; and (b) if they had suffered (regardless of witnessing or not any other attempt affecting third parties), at least once, a theft attempt while circulating within any of these two environments. Furthermore, and in case the participants positively responded to one of the previous questions, they were asked whether they modified their travel behavior as a consequence of this(these) experience(s) of victimization, providing a list of six different possible behaviors commonly adopted after suffering an on-trip victimization (i.e., Changing my mode/route of transportation; avoiding traveling alone; avoiding walking/using public transport when it is very crowded; avoiding walking/using public transport when it is very empty; modifying my travel schedules; staying on permanent alert).

\section{Ethics}

For this study, the Research Ethics Committee for Social Science in Health of the University Research Institute on Traffic and Road Safety (INTRAS) at the University of Valencia was consulted, and it granted the research's accordance with the principles stated in the Declaration of Helsinki for research with human subjects, since no personal data were involved, the participants' responses were treated with total anonymity and the risk level was determined as "very low" (IRB number HE0001251019). All participants gave us their consent to participate in the study after a careful reading of the Informed Consent form, in which the study aim, and all the aforementioned considerations were explained by the research staff.

\section{Data Processing}

First of all, we carried out an exhaustive data curation, in order to enhance the basic aspects of the data that were to be analyzed. Once the data was clean and properly labeled (41 incomplete surveys were discarded), basic descriptive analyses of the study sample were performed in order to characterize the participants of the study according to their demographic features and urban-travel patterns. Correlational analyses were performed through Spearman's rho or $r_{s}$, in order to determine the measures of association between the main study variables. 
TABLE 1 | Demographic data of the sample and transportation-related indicators.

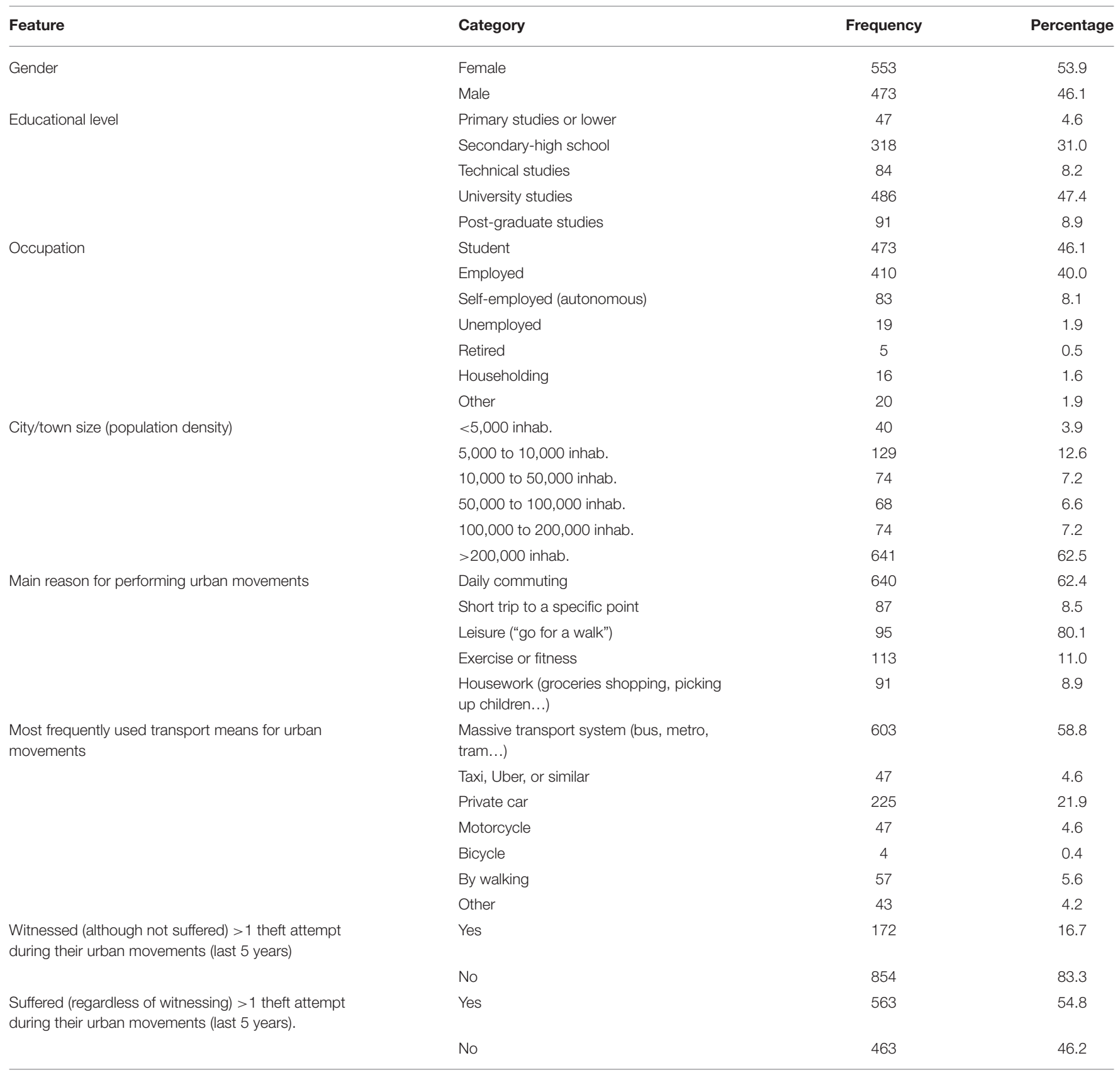

This test $\left(r_{s}\right)$ offers more accuracy for bivariate correlation's estimation when using both ordinal and scalar variables than Pearson's $r$ (Liu et al., 2016). Mean comparisons (One-way ANOVAs) were performed for comparing the scores given to numerical variables according to sex/gender, education, and city/town size. Finally, categorical analyses with Chi-square $\left(X^{2}\right)$ tests were used to establish relationships and differences between pairs of non-numerical variables. All statistical analyses were carried out using the Statistical Package for the Social Sciences (IBM SPSS Statistics), Version 23.0 (IBM Corporation, Armonk, NY, USA).

\section{RESULTS}

\section{Descriptive Findings and Correlational Analyses}

Apart from the data presented in the socio-demographic characterization of the sample, in Table 3 the means (M) and standard deviations (SD) of the main study variables are summarized. In short, it was found that the average duration of daily commuting trips of Dominican citizens was $75 \mathrm{~min}$, and their mean number of public transport trips per week was close to 6 , that is equivalent to three roundtrips a week. Furthermore, 
the average level of security perceived in the streets of their cities was 2.35 out of five, while the security perceived in the available public transport systems was 2.52 out of five.

In a second step, the ordinal and continuous variables included in the study were analyzed through Spearman's $\left(r_{s}\right)$ bivariate tests, finding interesting correlations between some pairs of them. Concretely:

- The age of Dominican citizens was negatively correlated to their number of trips performed by public transport in a week.

- The educational level was positively correlated to their daily commuting length, their weekly number of trips performed by public transport, and to the security perceived in the urban environment (i.e., city streets).

- The city/town size (population density) was negatively correlated to the level of security attributed to both city streets and public transportation systems. In other words, Dominicans from smaller cities/towns perceive their urban environments and public transport systems as more secure, if compared to inhabitants of larger/denser towns or cities. Also, the population density is positively correlated to the citizens' weekly number of trips performed by means of public transport.

TABLE 2 | Demographic comparisons between the sample features and country-based data.

\begin{tabular}{lccc}
\hline Variable & Category & $\begin{array}{c}\text { Study } \\
\text { sample } \\
\mathbf{( \% )}\end{array}$ & $\begin{array}{c}\text { Dominican } \\
\text { republic census }\end{array}$ \\
\hline Sex & Male & (\%) \\
\hline & Female & 46.1 & 50.17 \\
Age group & $\leq 24$ & 53.9 & 49.83 \\
& $25-34$ & 43,8 & 49.43 \\
Habitat & $35-50$ & 21.2 & 15.67 \\
& Urban $(>50,000$ inhabitants $)$ & 16.7 & 18.17 \\
& Rural $(<50,000$ inhabitants $)$ & 23.7 & 10.51 \\
& & 18.3 & 74.25 \\
\hline
\end{tabular}

a Data obtained from SICEN (http://sicen.one.gob.do/).
- The length of daily commuting trips (performed between home and/or the work/study place) was positively associated with the number of times that citizens used the public transport in a week. Also, the longer the daily commuting trips, the lower security level is perceived in both city streets and public transportation systems, and vice-versa (negative correlation).

- The number of weekly public transport-based trips was negatively associated with the level of security perceived in the urban environment and the security perceived in the public transport systems.

- Finally, a positive correlation between the levels of security perceived in the urban environment and the public transportation systems was also found. In other words, a person perceiving more security in the city streets tends to perceive a higher level of security on the public transport too, and vice versa.

\section{Mean Comparisons}

One-way Analyses of Variance (ANOVA) allowed us to determine the existence of a set of significant group differences between categories or groups, according to the three key demographic factors addressed in this study. In the case of citizens' sex, males perceive both city streets and public transport systems as safer than females. In addition, no significant differences in terms of weekly public transport use or daily commuting length were found.

As for Dominican citizens' educational level, significant differences were found in the case of all four contrasted variables, except for perceived security in urban environments, and the perceived security of both streets and public transport systems was tendentially higher for subjects with lower educational levels. Finally, and in what concerns e.g., city/town size intervals, it was found that inhabitants of mid-size towns $(5,000$ to 50,000 inhabitants) tendentially perceive transport systems as safer than citizens living in either small or large cities.

Post-hoc (Tukey) tests showed only slightly significant differences between specific levels (groups) for the variables tested with two or more categories (i.e., education and city size); this suggests a considerable homogeneity of the data across subjects when they are categorized by educational level and city/town size, as shown in Table 4. Specifically, for what

TABLE 3 | Descriptive statistics and bivariate (Spearman's $r_{s}$ ) correlations between study variables.

\begin{tabular}{|c|c|c|c|c|c|c|c|c|c|}
\hline \multicolumn{2}{|c|}{ Variable } & \multirow{2}{*}{$\begin{array}{l}\text { Mean } \\
31.88\end{array}$} & \multirow{2}{*}{$\begin{array}{c}\text { SD } \\
13.45\end{array}$} & \multirow{2}{*}{$\begin{array}{c}\mathbf{2} \\
-0.012\end{array}$} & \multirow{2}{*}{$\begin{array}{c}3 \\
0.046^{\star}\end{array}$} & \multirow{2}{*}{$\begin{array}{c}\mathbf{4} \\
-0.031\end{array}$} & \multirow{2}{*}{$\begin{array}{c}5 \\
-0.221^{\star \star}\end{array}$} & \multirow{2}{*}{$\begin{array}{c}6 \\
-0.026\end{array}$} & \multirow{2}{*}{$\begin{array}{c}\mathbf{7} \\
-0.026\end{array}$} \\
\hline 1 & Age & & & & & & & & \\
\hline 2 & Educational level ${ }^{a}$ & - & - & - & $0.107^{\star \star}$ & $0.063^{\star \star}$ & $0.046^{\star}$ & $0.049^{\star}$ & 0.015 \\
\hline 3 & City/town size ${ }^{a}$ & - & - & & - & 0.042 & $0.161^{\star \star}$ & $-0.106^{\star \star}$ & $-0.067^{\star \star}$ \\
\hline 4 & Daily Commuting Length (min.) & 74.93 & 51.20 & & & - & $0.200^{\star *}$ & $-0.167^{\star \star}$ & $-0.165^{\star \star}$ \\
\hline 5 & Public Transport trips a week & 5.68 & 3.75 & & & & - & $-0.174^{\star \star}$ & $-0.112^{\star \star}$ \\
\hline 6 & Perceived Security (City streets) & 2.35 & 1.23 & & & & & - & $0.632^{\star \star}$ \\
\hline 7 & Perceived Security (Public transport) ${ }^{b}$ & 2.52 & 1.24 & & & & & & - \\
\hline
\end{tabular}

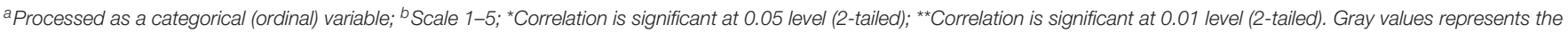
statistical correlation is not significant. 
TABLE 4 | Inter-group descriptive data (above) and mean comparisons (ANOVA; below) for security perception and urban trip-related factors according to sex, educational level, and city/town size interval (factors).

\begin{tabular}{|c|c|c|c|c|}
\hline Study variable & Category & Mean & SD & Std. error \\
\hline \multicolumn{5}{|l|}{ Factor 1: Sex } \\
\hline \multirow{2}{*}{$\begin{array}{l}\text { Perceived security } \\
\text { (City Streets) }\end{array}$} & Female & 2.20 & 1.21 & 0.05 \\
\hline & Male & 2.52 & 1.24 & 0.06 \\
\hline \multirow{2}{*}{$\begin{array}{l}\text { Perceived security } \\
\text { (Public Transport) }\end{array}$} & Female & 2.42 & 1.23 & 0.05 \\
\hline & Male & 2.63 & 1.25 & 0.06 \\
\hline \multirow{2}{*}{$\begin{array}{l}\text { Public transport } \\
\text { trips a week }\end{array}$} & Female & 5.81 & 3.69 & 0.16 \\
\hline & Male & 5.53 & 3.82 & 0.18 \\
\hline \multirow{2}{*}{$\begin{array}{l}\text { Daily commuting } \\
\text { length (min.) }\end{array}$} & Female & 82.80 & 70.19 & 3.31 \\
\hline & Male & 77.86 & 57.24 & 2.92 \\
\hline \multicolumn{5}{|c|}{ Factor 2: Educational level } \\
\hline \multirow[t]{5}{*}{$\begin{array}{l}\text { Perceived security } \\
\text { (City Streets) }\end{array}$} & $\begin{array}{l}\text { Primary studies or } \\
\text { lower }\end{array}$ & 2.57 & 1.45 & 0.22 \\
\hline & $\begin{array}{l}\text { Secondary-high } \\
\text { school }\end{array}$ & 2.40 & 1.28 & 0.07 \\
\hline & Technical studies & 2.46 & 1.25 & 0.14 \\
\hline & University studies & 2.33 & 1.21 & 0.06 \\
\hline & $\begin{array}{l}\text { Post-graduate } \\
\text { university studies }\end{array}$ & 2.10 & 1.10 & 0.12 \\
\hline \multirow[t]{5}{*}{$\begin{array}{l}\text { Perceived security } \\
\text { (Public Transport) }\end{array}$} & $\begin{array}{l}\text { Primary studies or } \\
\text { lower }\end{array}$ & 2.82 & 1.44 & 0.22 \\
\hline & $\begin{array}{l}\text { Secondary-high } \\
\text { school }\end{array}$ & 2.62 & 1.30 & 0.07 \\
\hline & Technical studies & 2.61 & 1.34 & 0.15 \\
\hline & University studies & 2.47 & 1.16 & 0.05 \\
\hline & $\begin{array}{l}\text { Post-graduate } \\
\text { university studies }\end{array}$ & 2.23 & 1.19 & 0.13 \\
\hline \multirow[t]{5}{*}{$\begin{array}{l}\text { Public Transport } \\
\text { trips a week }\end{array}$} & $\begin{array}{l}\text { Primary studies or } \\
\text { lower }\end{array}$ & 7.09 & 3.47 & 0.52 \\
\hline & $\begin{array}{l}\text { Secondary-high } \\
\text { school }\end{array}$ & 5.50 & 3.56 & 0.20 \\
\hline & Technical studies & 5.75 & 3.58 & 0.39 \\
\hline & University studies & 6.07 & 3.75 & 0.17 \\
\hline & $\begin{array}{l}\text { Post-graduate } \\
\text { university studies }\end{array}$ & 3.47 & 3.92 & 0.41 \\
\hline \multirow[t]{5}{*}{$\begin{array}{l}\text { Daily commuting } \\
\text { length (min.) }\end{array}$} & $\begin{array}{l}\text { Primary studies or } \\
\text { lower }\end{array}$ & 65.92 & 53.47 & 8.67 \\
\hline & $\begin{array}{l}\text { Secondary-high } \\
\text { school }\end{array}$ & 74.85 & 62.99 & 4.07 \\
\hline & Technical studies & 80.29 & 84.58 & 1.41 \\
\hline & University studies & 84.54 & 65.49 & 3.26 \\
\hline & $\begin{array}{l}\text { Post-graduate } \\
\text { university studies }\end{array}$ & 83.17 & 48.88 & 5.33 \\
\hline \multicolumn{5}{|c|}{ Factor 3: City/town size } \\
\hline \multirow{2}{*}{$\begin{array}{l}\text { Perceived security } \\
\text { (City Streets) }\end{array}$} & $<5,000$ inhab. & 2.30 & 1.36 & 0.22 \\
\hline & $\begin{array}{l}5,000 \text { to } 10,000 \\
\text { inhab. }\end{array}$ & 2.50 & 1.29 & 0.11 \\
\hline
\end{tabular}

TABLE $4 \mid$ Continued

\begin{tabular}{|c|c|c|c|c|}
\hline Study variable & Category & Mean & SD & Std. error \\
\hline & $\begin{array}{l}10,000 \text { to } 50,000 \\
\text { inhab. }\end{array}$ & 2.51 & 1.26 & 0.15 \\
\hline & $\begin{array}{l}50,000 \text { to } 100,000 \\
\text { inhab. }\end{array}$ & 2.54 & 1.22 & 0.15 \\
\hline & $\begin{array}{l}100,000 \text { to } \\
200,000 \text { inhab. }\end{array}$ & 2.47 & 1.13 & 0.13 \\
\hline & >200,000 inhab. & 2.27 & 1.22 & 0.05 \\
\hline \multirow{6}{*}{$\begin{array}{l}\text { Perceived security } \\
\text { (Public transport) }\end{array}$} & $<5,000$ inhab. & 2.63 & 1.39 & 0.22 \\
\hline & $\begin{array}{l}5,000 \text { to } 10,000 \\
\text { inhab. }\end{array}$ & 2.81 & 1.26 & 0.11 \\
\hline & $\begin{array}{l}10,000 \text { to } 50,000 \\
\text { inhab. }\end{array}$ & 2.76 & 1.32 & 0.15 \\
\hline & $\begin{array}{l}50,000 \text { to } 100,000 \\
\text { inhab. }\end{array}$ & 2.63 & 1.13 & 0.14 \\
\hline & $\begin{array}{l}100,000 \text { to } \\
200,000 \text { inhab. }\end{array}$ & 2.50 & 1.02 & 0.12 \\
\hline & >200,000 inhab. & 2.42 & 1.25 & 0.05 \\
\hline \multirow{6}{*}{$\begin{array}{l}\text { Public transport } \\
\text { trips a week }\end{array}$} & $<5,000$ inhab. & 5.75 & 4.11 & 0.65 \\
\hline & $\begin{array}{l}5,000 \text { to } 10,000 \\
\text { inhab. }\end{array}$ & 5.33 & 3.58 & 0.32 \\
\hline & $\begin{array}{l}10,000 \text { to } 50,000 \\
\text { inhab. }\end{array}$ & 5.53 & 3.48 & 0.41 \\
\hline & $\begin{array}{l}50,000 \text { to } 100,000 \\
\text { inhab. }\end{array}$ & 5.69 & 3.69 & 0.45 \\
\hline & $\begin{array}{l}100,000 \text { to } \\
200,000 \text { inhab. }\end{array}$ & 5.28 & 4.03 & 0.47 \\
\hline & >200,000 inhab. & 5.81 & 3.77 & 0.15 \\
\hline \multirow{6}{*}{$\begin{array}{l}\text { Daily commuting } \\
\text { length (min.) }\end{array}$} & $<5,000$ inhab. & 67.59 & 42.82 & 7.95 \\
\hline & $\begin{array}{l}5,000 \text { to } 10,000 \\
\text { inhab. }\end{array}$ & 73.33 & 65.56 & 6.59 \\
\hline & $\begin{array}{l}10,000 \text { to } 50,000 \\
\text { inhab. }\end{array}$ & 71.73 & 55.21 & 7.19 \\
\hline & $\begin{array}{l}50,000 \text { to } 100,000 \\
\text { inhab. }\end{array}$ & 85.85 & 78.30 & 1.76 \\
\hline & $\begin{array}{l}100,000 \text { to } \\
200,000 \text { inhab. }\end{array}$ & 82.50 & 57.05 & 7.49 \\
\hline & >200,000 inhab. & 82.78 & 65.55 & 2.83 \\
\hline ANOVA & $F^{\mathrm{a}}$ & & $d f^{b}$ & $\mathrm{Sig}^{\mathrm{c}}$ \\
\hline \multicolumn{5}{|l|}{ Factor 1: Sex } \\
\hline $\begin{array}{l}\text { Perceived security } \\
\text { (City Streets) }\end{array}$ & 17.150 & & $1,1,024$ & $<0.001$ \\
\hline $\begin{array}{l}\text { Perceived security } \\
\text { (Public Transport } \\
\text { System) }\end{array}$ & 7.261 & & & $<0.01$ \\
\hline $\begin{array}{l}\text { Public transport } \\
\text { trips a week }\end{array}$ & 1.428 & & & 0.232 \\
\hline $\begin{array}{l}\text { Daily commuting } \\
\text { length (min.) }\end{array}$ & 0.764 & & & 0.382 \\
\hline \multicolumn{5}{|c|}{ Factor 2: Educational level } \\
\hline $\begin{array}{l}\text { Perceived security } \\
\text { (City Streets) }\end{array}$ & 1.327 & & $5,1,020$ & $<0.250$ \\
\hline
\end{tabular}


TABLE 4 | Continued

\begin{tabular}{lccc}
\hline ANOVA & $F^{\mathbf{a}}$ & $\mathbf{d f}^{\mathbf{b}}$ & $\mathbf{S i g}^{\mathbf{c}}$ \\
\hline $\begin{array}{l}\text { Perceived security } \\
\text { (Public Transport }\end{array}$ & 2.402 & $<0.05$ \\
$\begin{array}{l}\text { System) } \\
\begin{array}{l}\text { Public transport } \\
\text { trips a week }\end{array}\end{array}$ & 123.255 & $<0.001$ \\
$\begin{array}{l}\text { Daily commuting } \\
\text { length (min.) }\end{array}$ & 933.65 & $<0.01$ \\
$\begin{array}{l}\text { Factor 3: City/town size interval } \\
\text { Perceived security }\end{array}$ & 1.701 & $5,1,020$ & \\
$\begin{array}{l}\text { (City Streets) } \\
\begin{array}{l}\text { Perceived security } \\
\text { (Public Transport }\end{array}\end{array}$ & & \\
$\begin{array}{l}\text { System) } \\
\text { Public transport } \\
\text { trips a week }\end{array}$ & 3.012 & \\
$\begin{array}{l}\text { Daily commuting } \\
\text { length (min.) }\end{array}$ & 0.567 & $<0.01$ \\
\hline
\end{tabular}

${ }^{a}$ Result of the F (One-way ANOVA) test; ${ }^{b}$ Degrees of freedom; ${ }^{c} p$-value.

concerns educational levels, no post-hoc differences were found for the perceived security, neither in urban environments nor in public transport systems. post-hoc differences for educational levels were only found in (i) the number of public transport trips performed a weeks, in which individuals with higher (postgraduate) educational levels performing significantly fewer trips than citizens with lower educational levels (primary to university studies). They were also found (ii) between individuals with secondary and university (graduate) studies, the latter having significantly longer commuting trips. As for city/town size, it was found that inhabitants from largest cities ( $>200,000$ inhabitants) perceive significantly less security in transport systems than those living in small towns (5,000-10,000 inhabitants).

\section{Categorical Analysis}

In addition to analyzing demographic factors, this study aimed to determine how urban safety issues may influence the travel behavior of participants. Hence, we analyzed the travel-related behavioral changes reported by: (i) 172 (16.7\% of the sample; $45 \%$ females and 55\% males; non-significant $X^{2}$ test for gender differences) participants who had witnessed theft attempts during the previous 5 years (either in the public transport or in the city's streets while commuting) without suffering them directly, and (ii) 563 (54.8\% of the sample; 52\% females, $48 \%$ males; non-significant $X^{2}$ test for gender differences) participants who reported that they had suffered at least one theft attempt (regardless of whether they had witnessed or not theft attempts affecting third parties) during the previous 5 years, as shown in Table 5.

Regarding the first case (participants witnessing theft attempts, although not suffering them), it was found that, after beholding an on-travel, theft-related security issue, participants did not significantly modify their routes, nor the transport means used for their movements [significant at $X_{(1)}^{2}=5.886, p<0.05$ ].
The most frequent behavioral pattern reported as a response to beholding theft attempts or similar incidents affecting other users (but not them) is rather being in a permanent state of alert $(60.5 \%)$ while traveling.

As for the second case, $54.9 \%$ of participants who suffered at least one on-travel theft attempt decided to modify their habitual daily transportation means or routes; for instance, by shifting from bus to taxi, or by choosing a different route for performing the same trip [significant at $X_{(1)}^{2}=33.970, p<$ 0.001]. Furthermore, other main actions taken by participants affected by theft attempts were: being permanently alert while traveling (55.8\%), avoiding traveling alone (40\%) and avoiding walking/using public transport when it is very empty $(36.1 \%)$.

\section{DISCUSSION}

The core aim of this research was to study the relationships between the security perceived in both urban environments and public transport systems, as well as the daily-travel behavior and patterns of the Dominican Republic's population. The results of this research suggest that demographic factors and urban travel patterns, as well as the perceived urban security, play an important role in the choice of transportation modes and other travel patterns of the Dominican population.

Particularly, the results of the current research have shown how, overall, Dominican citizen's perception of the public transportation security constitutes a pending issue for both public administrations and transport systems, especially if we consider that these outcomes are coherent with the ones gathered by the National Survey on Mobility of 2019 (INTRANT, 2020). The aforementioned survey also highlighted some interesting points on the "worst valued" elements of public transportation, that were: comfort, hygiene, and, once again, users' security.

Furthermore, previous studies carried out in the region (i.e., other Latin American countries), for instance in Ecuador (Núñez et al., 2018), Argentina (Pereyra et al., 2018) and Colombia (Cámara de Comercio de Bogotá, 2018) have coherently documented similar trends: in short, all of them suggest that even though citizens do not present a high level of dissatisfaction with public transportation, many of them report having frequently found themselves in situations of unsafety or harassment during their urban trips. Therefore, it is indeed surprising to find such a high use of this transport mode among Dominican citizens. One reasonable assumption in this regard is that, due to -as it is mentioned in the introduction- the several economic and social disparities present in the country (Carneiro and Sirtaine, 2017), the great majority of Dominicans might find the most accessible and affordable option for their daily urban trips in public transportation (INTRANT, 2020); one of the reasons is that, for instance, the economic investment represented by buying and maintaining a private vehicle remains challenging for a very low-income population that predominantly works under a lack of job security (Carneiro and Sirtaine, 2017).

The results of the present study show that the more security is perceived in the streets, the fewer trips are performed by public transportation. In this sense, there are studies demonstrating that 
TABLE 5 | Travel actions taken by study participants after witnessing or suffering a theft attempt in city streets and/or public transport.

\begin{tabular}{|c|c|c|c|c|}
\hline \multirow[t]{2}{*}{ Action } & \multicolumn{2}{|c|}{ Yes } & \multicolumn{2}{|c|}{ No } \\
\hline & Frequency & Percentage & Frequency & Percentage \\
\hline \multicolumn{5}{|l|}{ (i) Witnessing theft attempts } \\
\hline Changing my mode/route of transportation & 53 & 30.8 & 119 & 69.2 \\
\hline Avoiding traveling alone & 47 & 27.3 & 125 & 72.7 \\
\hline Avoiding walking/using public transport when it is very crowded & 33 & 19.2 & 139 & 80.8 \\
\hline Avoiding walking/using public transport when it is very empty & 50 & 29.1 & 122 & 70.9 \\
\hline Modifying my travel schedules & 40 & 23.3 & 132 & 76.7 \\
\hline Staying on permanent alert & 104 & 60.5 & 68 & 39.5 \\
\hline \multicolumn{5}{|l|}{ (ii) Suffering theft attempts } \\
\hline Changing my mode/route of transportation & 309 & 54.9 & 254 & 45.1 \\
\hline Avoiding traveling alone & 225 & 40.0 & 338 & 60.0 \\
\hline Avoiding walking/using public transport when it is very crowded & 157 & 27.9 & 406 & 71.1 \\
\hline Avoiding walking/using public transport when it is very empty & 203 & 36.1 & 360 & 63.9 \\
\hline Modifying my travel schedules & 167 & 29.7 & 396 & 70.3 \\
\hline Staying on permanent alert & 314 & 55.8 & 249 & 44.2 \\
\hline
\end{tabular}

the perception of security in a certain area encourages people to move on foot or to use a bike (Dennis et al., 2019; Nostikasari et al., 2019). Therefore, it is logical that these people will diminish their use of public transportation. Also, a positive relation was detected between the perception of security in the streets and the perception of security in public transportation. In this sense, it is remarkable that the longer the trips performed by public transport, the lower is the perception of their security. This could be related to the fact that spending more time on these vehicles increases the probability of experiencing a dangerous situation, either personally or as a witness.

In this sense, it is also expectable that females may perceive public transportation means as less secure than males, since they are the ones using it the most, especially if the typical gendergaps of emerging countries are kept in mind (Núñez et al., 2018; Pereyra et al., 2018). In this regard, there is empirical evidence on women using public transportation in violent areas who usually display more fear or concern, even in locations in which males are those getting more involved in violent accidents and/or security incidents (Quiñones et al., 2018). To this we must add that Latin American public transport systems present a high incidence of harassment, mostly affecting women, as observed in many other locations in the region (Gardner et al., 2017; Orozco-Fontalvo et al., 2019). Accordingly, this set of differences between men and women are highlighted in several researches, with females always standing out as the most frequent victims of harassment-related incidents (Ibarra and Castro, 2016; Falú, 2017; Orozco-Fontalvo et al., 2019).

Complementarily, other differential factor are age and city/town density. In regard to the first one, this study found that older people perceive more security flaws and shortcomings in public transportation, as observed, for instance, in a recent study carried out in Peru (Huamani et al., 2019). As for the second factor, there is a tendency to develop a lower perception of security if the size of the town of residence is bigger. It is important to distinguish whether such a perception is adjusted to the real data on crime or, on the other hand, if it is a false/biased perception, which may take place more frequently in urban environments (Prieto and Richard, 2016).

Lastly, and in regard to those citizens witnessing and/or suffering threatening situations during urban trips, the most frequently performed behavioral action was increasing the level of alert. From a psychological perspective, it makes sense to assume that the increase of anxiety and alert levels are among the most common responses after facing hazardous situations, potentially implying behavioral, physical, cognitive and emotional consequences (Muggah and de Boer, 2019). The present study also points out that "changing route" or "avoiding traveling alone" are relatively frequent behaviors. Also, it is remarkable that, for what concerns these situations, there are few public transport users who actually avoided using the transportation systems or vehicles when it is almost empty (this is a difficult factor to control if, for instance, work schedules are inflexible and end too late), in comparison with avoiding it when it is crowded. In this regard, similar studies have especially focused on the relationship between isolated public transport environments and higher levels of anxiety and lower levels of perceived security (Davidson et al., 2016; Orozco-Fontalvo et al., 2019).

\section{CONCLUSION}

The results of this study suggest that perceived security, both in urban environments and public transport systems, is a relevant issue that affects the daily and transport-related patterns and behavioral choices of the Dominican Republic population, and it constitutes a core issue to address in transport planning. Furthermore, and although there are no differences in terms of witnessing or suffering a crime-attempt, there are significant 
gender-based differences in the security perception of these two environments: women perceive a higher lack of security in both scenarios.

This research establishes a starting point for the elaboration of adequate strategies aimed at strengthening the promotion of safer and more sustainable public transportation means and urban environments, considering the income-state and the high demand of public transportation among most of the population in the Dominican Republic, as well as in other countries of the region with similar income-related and demographic characteristics.

\section{Limitations of the Study}

Although our sample size was considerably large and representative of the Dominican population, and all statistical parameters were accurately and positively tested during the data analysis, some key technical issues must be acknowledged as potential sources of bias. First, this study is based on self-reports, placing its results within the spectrum of the common method biases, often observed in research with cross-sectional designs (Cossman and Rader, 2011; Simundić, 2013). These sources of bias may range from social desirability to lack of sincerity and acquiescence bias. Also, if we consider that the survey addressed a set of topics embodied in the current social discussions, several social concerns related to factors such as poverty, inequalities, and lack of safety may emerge, as observed in previous studies dealing with topics perceived as sensitive by the population, such as crime, fear of crime, and victimization (Sutton and Farrall, 2005; Derksen, 2012). In short, this kind of topics are usually stigmatized, and therefore still tend to affect study outputs, although the anonymity of participation and the scientific value of the data were clearly guaranteed prior to the individual's partaking in the study. Finally, there are two technical issues that should be acknowledged as limitations of this study as well: (i) The sampling procedure was not probabilistic, but rather based on the willingness to participate showed by individuals interviewed by the research staff on the city streets. This could therefore bias the study outcomes, to a certain extent (e.g., what about the perception of individuals who hardly go out, or non-respondents' profiles?); (ii) For assessing perceived security both in urban locations and public transport systems, single item-based variables were used. In this regard, for further studies it is suggestible to use multi-item scales for measuring critical

\section{REFERENCES}

Alm, C., and Lindberg, E. (2002). Perceived Security in Public Transport. Linköping: Swedish National Road and Transport Research Institute (VTI).

Arriagada, I., and Godoy, L. (2000). Prevenir o reprimir: falso dilema de la seguridad ciudadana. Rev. CEPAL 2000, 107-131. doi: 10.18356/cef3a45a-es

Beirão, G., and Cabral, J. S. (2007). Understanding attitudes towards public transport and private car: a qualitative study. Transp. Policy 14, 478-489. doi: 10.1016/j.tranpol.2007.04.009

Cámara de Comercio de Bogotá (2018). Encuesta de Percepción y Victimización en Bogotá-Primer Semestre de 2018. Bogotá: Cámara de Comercio de Bogotá.

Cantarella, G. E., and Cascetta, E. (1995). Dynamic processes and equilibrium in transportation networks: towards a unifying theory. Transp. Sci. 29, 305-329. doi: $10.1287 / \operatorname{trsc} .29 .4 .305$ issues such as security perceptions, that may allow researchers to retrieve more specific information on these issues. Performing complementary procedures, such as testing questionnaire reliability, is also highly advisable.

\section{DATA AVAILABILITY STATEMENT}

The raw data supporting the conclusions of this article will be made available by the authors, under reasonable request.

\section{ETHICS STATEMENT}

The study design and protocol were reviewed and approved by the RESEARCH ETHICS COMMITTEE of the University Research Institute on Traffic and Road Safety at the University of Valencia (IRB HE0001251019).

\section{AUTHOR CONTRIBUTIONS}

All authors contributed to the design of the study and also wrote the final manuscript. FA drew up the study design with the help of SU, the rest of the authors also contributed. MF and SU were in charge of the data revision. CE also drafted the manuscript. FA performed the statistical analysis. All authors read and approved the final manuscript.

\section{FUNDING}

This study was funded by the National Institute of Transit and Land Transportation (INTRANT) and its Permanent Observatory in Road Safety (OPSEVI; public agency of the Dominican Republic) - Grant number: 20170475.

\section{ACKNOWLEDGMENTS}

The authors wish to thank all participants of the study and the institutional stakeholders, such as the National Institute of Transit and Land Transportation (INTRANT) and its Permanent Observatory in Road Safety (OPSEVI; public agency of the Dominican Republic), providing support and technical advising to the study. Special thanks to Runa Falzolgher for the professional edition of the manuscript.

Carneiro, F. G., and Sirtaine, S. (2017). When Growth Is Not Enough: Explaining the Rigidity of Poverty in the Dominican Republic. Directions in Development. Washington, DC: World Bank.

Chaurand, N., and Delhomme, P. (2013). Cyclists and drivers in road interactions: a comparison of perceived crash risk. Accid. Anal. Prev. 50, 1176-1184. doi: 10.1016/j.aap.2012.09.005

Cossman, J. S., and Rader, N. E. (2011). Fear of crime and personal vulnerability: examining self-reported health. Sociol. Spectr. 31, 141-162. doi: 10.1080/02732173.2011.541339

Davidson, M. M., Butchko, M. S., Robbins, K., Sherd, L. W., and Gervais, S. (2016). The mediating role of perceived safety on street harassment and anxiety. Psychol. Violence 6, 553-561. doi: 10.1037/a0039970

Dennis, W., Xiao, W., Medina, R., and Tian, G. (2019). Effects of neighborhood environment, safety, and urban amenities on origins and destinations 
of walking behavior. Urban Geogr. 1-21. doi: 10.1080/02723638.2019. 1699731

Derksen, S. W. (2012). Gender, social desirability, and fear of crime: are women really more afraid? (Doctoral thesis). University of Manitoba, Winnipeg, MB, Canada.

Falú, A. (2017). The stigmatizing force of sexual harassment: violence on public transport. Vivienda Ciudad 4, 205-209.

Gardner, N., and Cui, J., and Coiacetto, E. (2017). Harassment on public transport and its impacts on women's travel behaviour. Aust. Plann. 54, 8-15. doi: 10.1080/07293682.2017.1299189

Herman, R., Montroll, E. W., Potts, R. B., and Rothery, R. W. (1959). Traffic dynamics: analysis of stability in car following. Oper. Res. 7, 86-106. doi: 10.1287/opre.7.1.86

Ho, H. C., Leono, D., Suhartono, I. S., and Reynaldo, M. (2015). "Pursuing the quality of driving through an understanding of job security, job satisfaction, and perceived safety as antecedents of motorcycling behaviors in Jakarta, Indonesia," in 2015 International Conference on Industrial Engineering and Operations Management (IEOM) (Dubai).

Ho, H. C., and Widaningrum, D. L. (2016). "Car drivers with higher perceived safety tend to drive their vehicles with higher risk, a unique phenomenon on the roads in Jakarta, Indonesia," in Proceedings of the 2016 International Conference on Industrial Engineering and Operations Management (Kuala Lumpur).

Huamani, J. C., Lazo, M. C., and Calizaya, J. M. (2019). Perception of citizen security in residents of a district of the city of Arequipa. Rev. Invest. Psicol. 22, 95-110. doi: 10.15381/rinvp.v22i1.16584

Ibarra, L. F. B., and Castro, M. V. (2016). Women, space and power: city and public transport as exclusion devices. Reflections from the city of Cali. Rev. Estud. Soc. Juríd. 18, 227-252. doi: 10.12804/esj18.02.2016.08

ILPES (1997). Guía Para la Identificación, Preparación y Evaluación de Proyectos de Seguridad Pública, LC/IP/L.149, Versión Preliminar. Santiago de Chile: Instituto Latinoamericano y del Caribe de Planificación Económica y Social.

INTRANT (2020). National Mobility Survey of the Dominican Republic. Results REPORT 2019. Santo Domingo: Instituto Nacional de Tránsito y Transporte Terrestre.

Kim, J.-K., Kim, S., Ulfarsson, G. F., and Porrello, L. A. (2007). Bicyclist injury severities in bicycle-motor vehicle accidents. Accid. Anal. Prev. 39, 238-251. doi: 10.1016/j.aap.2006.07.002

Lai, W.-T., and Chen, C.-F. (2011). Behavioral intentions of public transit passengers-the roles of service quality, perceived value, satisfaction and involvement. Transp. Policy 18, 318-325. doi: 10.1016/j.tranpol.2010.09.003

Liu, J., Tang, W., Chen, G., Lu, Y., Feng, C., and Tu, X. M. (2016). Correlation and agreement: overview and clarification of competing concepts and measures. Shanghai Arch. Psychiatry 28, 115-120. doi: 10.11919/j.issn.1002-0829.216045

Muggah, R., and de Boer, J. (2019). Security Sector Reform and Citizen Security: Experiences From Urban Latin America in Global Perspective. London: London Ubiquity Press. doi: 10.5334/bcc

Muro-Rodríguez, A. I., Perez-Jiménez, I. R., and Gutiérrez-Broncano, S. (2017). Consumer behavior in the choice of mode of transport: a case study in the toledo-madrid corridor. Front. Psychol. 8:1011. doi: 10.3389/fpsyg.2017. 01011

Nostikasari, D., Haile, G., Patterson, G., Malek, G., Walkin, I., and Shelton, K. (2019). Safe Streets, Safe Communities: Walking and Biking Infrastructure in Gulfton. Houston, TX: Kinder Institute for Urban Research.
Núñez, F. M., Freire, C., and Vayas, T. (2018). Sondeo de opinión ciudadana a los usuarios de transporte público en el cantón Ambato. Bolentín Coyuntura 1, 11-15. doi: 10.31164/bcoyu.16.2018.661

Orozco-Fontalvo, M., Soto, J., Arévalo, A., and Oviedo-Trespalacios, O. (2019). Women's perceived risk of sexual harassment in a bus rapid transit (BRT) system: the case of Barranquilla, Colombia. J. Transp. Health 14:100598. doi: 10.1016/j.jth.2019.100598

Pereyra, L. P., Gutiérrez, A., and Mitsuko-Nerome, M. (2018). Insecurity in public transport in the buenos aires metropolitan area. Experiences and perceptions of women and men. Territorios 39, 71-95. doi: 10.12804/revistas.urosario.edu.co/territorios/a.6310

PNUD (1998). Desarrollo Humano en Chile 1998: Las Paradojas de la Modernización. Santiago de Chile: Programa de las Naciones Unidad para el Desarrollo.

Prieto, R., and Richard, S. (2016). A metric of the difference between perception of security and victimization rates. Crime Sci. 5:12. doi: 10.1186/s40163-016-0060-y

Quiñones, F. G., Contreras, C. P., and Rodríguez, C. R. J. (2018). Vulnerability in public transport: quantitative analysis of perceptions of safe mobility. Rev. Urbanismo 39, 1-14. doi: 10.5354/0717-5051.2018.49399

Sánchez-Flores, Ó., and De Palma, A. (2013). Reflection on approaches and methods used in transport science. Econ. Soc. Territorio 13, 751-778.

Schneider, R. J. (2013). Theory of routine mode choice decisions: an operational framework to increase sustainable transportation. Transp. Policy 25, 128-137. doi: 10.1016/j.tranpol.2012.10.007

Simundić, A. M. (2013). Bias in research. Biochem. Med. 23, 12-15. doi: 10.11613/BM.2013.003

Sutton, R. M., and Farrall, S. (2005). Gender, socially desirable responding and the fear of crime: are women really more anxious about crime? Br. J. Criminol. 45, 212-224. doi: 10.1093/bjc/azh084

Syed, S. T., Gerber, B. S., and Sharp, L. K. (2013). Traveling towards disease: transportation barriers to health care access. J. Commun. Health 38, 976-993. doi: 10.1007/s10900-013-9681-1

Vidales, C. (2012). Citizen security, security policies and police strategies. Estud. Penales Criminol. 32, 469-502.

Waller, M., Meixell, M. J., and Norbis, M. (2008). A review of the transportation mode choice and carrier selection literature. Int. J. Logistics Manag. 19, 183-211. doi: 10.1108/09574090810895951

Zhang, J., Fujiwara, A., and Chikaraishi, M. (2005). Comparative analysis of travel patterns in the developing cities based on a hybrid model. J. East. Asia Soc. Transp. Stud. 6, 4333-4348. doi: 10.11175/easts.6.4333

Conflict of Interest: The authors declare that the research was conducted in the absence of any commercial or financial relationships that could be construed as a potential conflict of interest.

Copyright (c) 2020 Alonso, Useche, Faus and Esteban. This is an open-access article distributed under the terms of the Creative Commons Attribution License (CC BY). The use, distribution or reproduction in other forums is permitted, provided the original author(s) and the copyright owner(s) are credited and that the original publication in this journal is cited, in accordance with accepted academic practice. No use, distribution or reproduction is permitted which does not comply with these terms. 